\title{
CMA president drafts prescription for Canadian health care
}

\author{
Early released Aug. 21, 2008
}

$\mathrm{D}$ r. Robert Ouellet has evaluated Canada's health care system, and his diagnosis is grim.

"The overall assessment of the Canadian health care system is alarming," he said Aug. 20, 2008, in his inaugural address as president of the Canadian Medical Association (CMA). "We have one of the most costly and least efficient health systems of any industrialized nation. We need to fix it. We need to fix it, now."

In his wide-ranging address, Ouellet also argued for creating a universal drug access program, adopting patientbased funding, and improving working conditions and pay for doctors.

Despite his ominous opening about the health care's systems ailments, Ouellet assured delegates to the CMA's 141st annual general council in Montréal, that transforming Canada's health system is possible. "My message to you today is: we can do it."

Ouellet, a radiologist who owns and operates five medical imaging clinics in suburban Montréal, labelled himself as a man of action, and promised, as president, to work to overcome resistance to change, to rise above differences of opinion and to encourage all health care stakeholders to leave their prejudices behind.

The two biggest challenges facing the health care system, said Ouellet, are ensuring viability and improving access. Like his predecessor, Dr. Brian Day, Ouellet believes that integrating private care into the health system is part of the solution to these problems.

He does not, however, believe that the system should be entirely privatized.
Instead, he favours a private-public mix. Ouellet said he realizes that "private health care" is, for many Canadians, a repugnant phrase. But "the fact is that the private system exists and, like it or not, is here to stay. We need to accommodate it in order for the public system to prosper."

Ouellet vowed to continue Day's efforts to promote a patient-focused health care funding model. The globalfunding model should be abolished, he said, in favour of a model that rewards results and promotes efficiency, effectiveness and effort. "Patients should not be seen as a cost to the system, but the very raison d'être of the system."

He also stressed the importance, if the health system is to remain viable, of finding new forms of funding. Offering few details, Ouellet said that could involve a health account or a Medicare fund.

But whatever form it takes, Ouellet added, physicians must help ensure the cost burden is not simply passed to future generations.

In terms of improving access, Ouellet said increasing the number of physicians in Canada is a top priority. In 1970, Canada ranked fourth among developed nations in terms of the ratio of physicians to population, but the nation has since plummeted to 26 th place, he noted.

To attract and keep doctors, Canada must offer competitive salaries and adequate working conditions, he said. "We need a system that treats health professionals, hospitals and, most importantly, patients, as value centres, not cost centres."
Ouellet also stressed the importance of ridding Canada of the "burden of waiting lists" and of increasing investment in electronic medical records.

Calling it "scandalous" that 3.5 million Canadians don't have access to prescription drugs, Ouellet proposed the creation of a universal prescription drug access program.

It could be modelled on Quebec's current program, he said. "Why reinvent the wheel when we can look within our own borders for a program that works?"

Ouellet, who hails from Longueuil, Quebec, obtained a medical degree from L'Université de Montréal in 1970. He later earned a certificate of specialty in diagnostic radiology, also from L'Université de Montréal. After completing his training, Ouellet set up practice in Quebec's Mauricie region, where, in 1978, he founded and directed the Clinique De Radiologie Des Récollets. In 1984, he moved to the Montréal area. A year later, he became head of Cité de la Santé de Laval.

He first ventured into the private sector in 1987, when, with several colleagues, he founded Tomo-Concorde, Canada's first private axial tomography clinic. In 1997, he opened his first medical imaging clinic.

Ouellet served as treasurer and vicepresident of the Quebec Medical Association before being elected to the presidency in 2005. Since 2003, Ouellet has also been a CMA board member. He is married to Diane Marceau and has three children. — Roger Collier, CMAJ

CMAJ 2009. DOI:10.1503/cmaj.081324 